\title{
Ladle Slag of Electric Steelmaking as Alkaline Agent on Controlling of Acid Mine Drainage Generation
}

\author{
Luciana Angelita Machado ${ }^{1}$, Luisa Ventura de Freitas ${ }^{2}$, Pedro Ivo Chitolina Villetti ${ }^{2}$, \\ Rejane Maria Candiota Tubino ${ }^{1}$, Ivo André Homrich Schneider ${ }^{1}$ \\ ${ }^{1}$ Programa de Pós-Graduação em Engenharia de Minas, Metalúrgica e de Materiais, School of Engineering, Universidade Federal do \\ Rio Grande do Sul, Porto Alegre, Brazil; ${ }^{2}$ Environmental Engineering, School of Engineering, Universidade Federal do Rio Grande \\ do Sul, Porto Alegre, Brazil. \\ Email: luciana.machado@erechim.ifrs.edu.br, ivo.andre@ufrgs.br
}

Received October $1^{\text {st }}, 2013$; revised November $2^{\text {nd }}, 2013$; accepted November $28^{\text {th }}, 2013$

Copyright (C) 2013 Luciana Angelita Machado et al. This is an open access article distributed under the Creative Commons Attribution License, which permits unrestricted use, distribution, and reproduction in any medium, provided the original work is properly cited. In accordance of the Creative Commons Attribution License all Copyrights (C) 2013 are reserved for SCIRP and the owner of the intellectual property Luciana Angelita Machado et al. All Copyright $\mathbb{C} 2013$ are guarded by law and by SCIRP as a guardian.

\begin{abstract}
Commercial coal production in the southern region of Brazil (comprising the Paraná, Santa Catarina, and Rio Grande do Sul states) has been occurring since the beginning of the twentieth century. Regarding the Santa Catarina coalfields, about $60 \%-65 \%$ of the ROM coal is discharged at dump deposits as waste. These wastes can lead to the formation of acid mine drainage (AMD), a source of ground and surface water pollution. One of the technologies used for preventing AMD consists of the alkaline additive method. Thus, the aim of this work was to study, at laboratory scale, the DAM control by blending coal waste with a metallurgical slag. A coal-tailing sample was collected from a coal mine, and the slag was obtained from a semi-integrated steel plant. Static tests were carried out by the acid-base account method to determine the balance between the acid-producing and acid-consuming (neutralizing) mineral components of the samples. Kinetic tests were conducted in humidity cells, following the ASTM D 5744-96 method, for a period of 80 weeks. The results showed that the coal tailing generates AMD. However, environmental problems can be minimized by mixing the coal waste with the metallurgical slag in $1: 1$ or $1: 1.5$ proportions. The kinetic experiments proved that, in this condition, the lixiviation presents a higher $\mathrm{pH}$ and a lower concentration of acidity, metals, and sulfate. Finally, it is possible to conclude that the blending slag in coal tailing deposits can be a viable alternative for DAM control in coal mining.
\end{abstract}

Keywords: Acid Mine Drainage; Coal Waste; Ladle Slag of Electric Steelmaking; Pollution Control

\section{Introduction}

The production of coal in Brazil is concentrated in the southern region of the country. According to 2012 data from the National Department of Mineral Production, the State of Rio Grande do Sul (RS) is the largest producer of coal, with $54.8 \%$ of the total production, Santa Catarina (SC) with $43.6 \%$, and Paraná (PR) with only $1.5 \%$. [1]. The extraction of coal may be done in an open pit or in underground mines, depending on the depth of the layer. Mining activities (extraction, ore concentration, and deactivation after mine closure) move large amounts of material in a short period of time, generating great amounts of waste (barren mining and beneficiation tailings). The arrangement of these materials should be per- formed under conditions that do not cause negative effects to the environment. Therefore, it is necessary to observe a number of criteria, such as selecting the right site for layout and preparing the ground to prevent runoff and infiltration of contaminants with the aim of preventing the formation of acid mine drainage (AMD).

AMD is a serious environmental problem that could affect the quality of water resources close to the area where it occurs. AMD results from oxidation of metal sulfides in the presence of air and water. This type of pollution is common in coal mining areas, due to the levels of iron sulfide $\left(\mathrm{FeS}_{2}\right)$ in the tailings. These sources remain active for decades and even centuries. Annually, worldwide, considerable amounts of resources are in- 
tended to correct the environmental problems of the acidity [2].

AMD can be controlled by means of preventive and remediation methods [2]. The alkaline additive is a preventive method based on the mixture of alkali materials with the mining waste. In this context, the static and kinetic tests are designed to evaluate the potential and evolution of acidity generation. The static tests are quick and enable the application of specific criteria that provide the classification of the materials according to their acidity generation potential. Furthermore, they allow quantifying the amount of alkali materials to avoid acidity generation. The kinetic tests provide information on the rate of sulfide mineral oxidation and therefore acid production, as well as an indication of drainage water quality [3].

Thus, the aim of this work was to study, at laboratory scale, the AMD control by blending coal waste with a metallurgical slag. Both materials were characterized and static and kinetic tests were conducted in order to establish a proper ratio between the materials to avoid the generation of AMD.

\section{Materials and Methods}

The coal waste (CW) was supplied by a mining company in Santa Catarina State, Brazil, that extracts and beneficiates the "Barro Branco" coal seam. Sample of Ladle Slag of Electric Steelmaking (LSES) was obtained from a semi-integrated mill that produces special steels, in the state of Rio Grande do Sul, Brazil. The materials were processed to obtain a representative sample, following the procedures described at NBR 10007 [4].

The metal analysis of CW and LSES were carried by atomic absorption spectrophotometry following the EPA method 3052 [5]. The mineralogical composition of the samples was performed by $x$-ray diffraction (XRD). The $\mathrm{XRD}$ patterns were obtained using an $\mathrm{x}$-ray diffractometer, using a Cuk $\alpha$ radiation $(\lambda=1.406 \AA)$, voltage $40 \mathrm{kV}$, and a current of $30 \mathrm{~mA}$. The samples were also analyzed for ash content, volatile matter, and fixed carbon. The ash analyses were performed according to NBR 8289 [6]. The volatile matter was determined according to NBR 8290 [7]. The values obtained were corrected for the moisture content. Analyses of moisture content were performed according to NBR 8293 [8]. The determination of fixed carbon was calculated by difference, subtracting the amount of ash and volatile matter, in dry basis, from one hundred percent [9].

The static tests were performed by the Acid Base Accounting (ABA) method. The purpose was to determine the balance between production and consumption of acidity (neutralization) by the mineral components of the samples of CW and LSES $[2,10]$. In order to perform the static tests, two preliminary tests were carried out: paste
$\mathrm{pH}$, to identify the conditions of acidity or alkalinity of the samples, and the fizz rating, to set the volume and concentration of hydrochloric acid to be used in determining neutralization potential $[2,10]$.

The determination of acidity potential (AP) was carried out from the analysis of total sulfur using a leco analyzer [11]. AP was calculated by the following conversion factor:

$$
\mathrm{AP}=31.25 \times \% \mathrm{~S} .
$$

To determine the neutralizing potential (NP), the procedure consisted of subjecting the sample to an acidic solution followed by titration of the acid solution with sodium hydroxide (with the same concentration of acid) to $\mathrm{pH}$ 7.0. The net neutralization potential (NNP), or acid/base account (ABA) was determined by subtracting the AP from the NP:

$$
\mathrm{NNP}=\mathrm{NP}-\mathrm{AP} .
$$

Units for static test results (AP, NP, and NNP) were expressed $\mathrm{kg} \mathrm{CaCO}_{3}$ per metric tons of rock. NNP values $<20 \mathrm{~kg} \cdot \mathrm{CaCO}_{3} \cdot \mathrm{t}^{-1}$ indicate that the material generates AMD, NNP values $>20 \mathrm{~kg} \cdot \mathrm{CaCO}_{3} \cdot \mathrm{t}^{-1}$ indicate that the material does not generate the AMD, and NNP values between -20 and $20 \mathrm{~kg} \cdot \mathrm{CaCO}_{3} \cdot \mathrm{t}^{-1}$ show a state of uncertainty $[3,12]$.

Kinetic tests were performed by the Humidity Cell Test, according to procedure D 5744 [13] (Figure 1). Four cells were used for holding the damp kinetic assay: a cell filled with CW, another cell filled with LSES, and two other cells filled with a mixture of CW:LSES in a ratio of 1:1 (NNP equal to zero) and in a ratio of 1:1.5 (considering a safety factor of 1.5). The tests consisted of placing 1000 grams of the material, with particle size between $6.3 \mathrm{~mm}$ and $2.0 \mathrm{~mm}$, in the column. During the seven day cycle, dry air was passed through the sample container for the first three days and humidified air for the next three days. On the seventh day the sample was

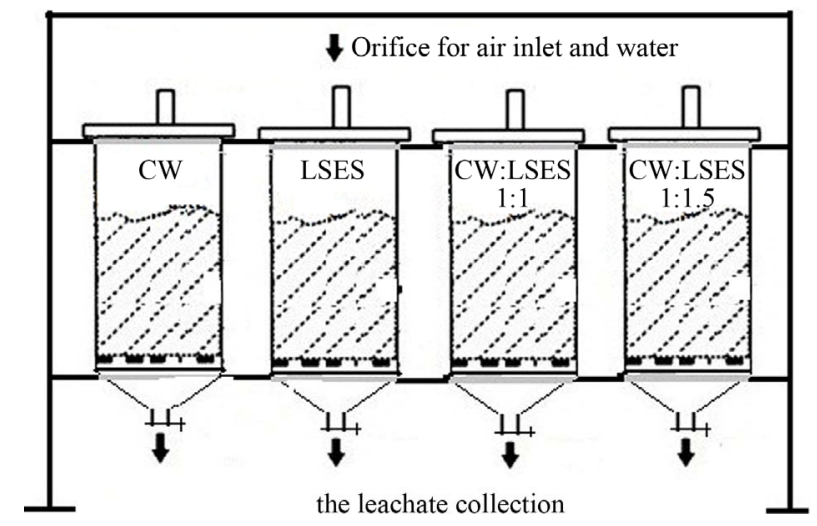

Figure 1. Scheme of the experimental assembly of humid cells for the kinetic tests' with coal waste $(\mathrm{CW})$, ladle slag of electric steelmaking furnace (LSES), and complete mixtures of CW:LSES in the ration of $1: 1$ and 1:1.5. 
rinsed with $500 \mathrm{~mL}$ of distilled water. The leachate was collected and analyzed for the following water quality parameters: $\mathrm{pH}$, Eh, acidity, alkalinity, and concentration of metals (Fe total, Al, Mn, Zn, Cr) and sulfate. Analyses were conducted weekly, following the procedures of the Standard Methods for the Examination of Water and Wastewater [14]. This experiment was carried out for eighty weeks, to observe the quality of the leaching solution over this period of time.

\section{Results and Discussion}

Table 1 shows the elemental analysis of the CW and LSES. It can be observed that the coal waste is rich in $\mathrm{Si}$, $\mathrm{Fe}$ and Al. This can be confirmed by the results of the mineralogical composition of the coal waste, consisting mainly of the following crystalline compounds: quartz $\left(\mathrm{SiO}_{2}\right)$, pyrite $\left(\mathrm{FeS}_{2}\right)$, kaolinite $\left(\mathrm{Al}_{2} \mathrm{Si}_{2} \mathrm{O}_{5}(\mathrm{OH})_{4}\right)$, calcite $\left(\mathrm{CaCO}_{3}\right)$ and llite $\left(\mathrm{K}_{1-1.5} \mathrm{Al}_{4}\left[\mathrm{Si}_{7-6.5} \mathrm{Al}_{1-1.5} \mathrm{O}_{20}\right](\mathrm{OH})_{4}\right)$. In the case of LSES, the higher concentrations are $\mathrm{Al}, \mathrm{Ca}$, $\mathrm{Fe}, \mathrm{Cr}$, and $\mathrm{Si}$. The presence of $\mathrm{Cd}, \mathrm{Co}, \mathrm{Cu}, \mathrm{Ni}$, and $\mathrm{Pb}$ was also detected, but in lower concentrations. Analyzing the mineralogical characteristics of the slag in the study, the most intense peaks are assigned gehlenite $\left(\mathrm{Ca}_{2} \mathrm{Al}_{2} \mathrm{Si}_{2} \mathrm{O}_{7}\right)$ marwinita $\left(\mathrm{Ca}_{3} \mathrm{Mg}\left(\mathrm{SiO}_{4}\right)_{2}\right)$, calcium oxide $(\mathrm{CaO})$, magnetite $\left(\mathrm{Fe}_{3} \mathrm{O}_{4}\right)$, wustite $(\mathrm{FeO})$ and periclase $(\mathrm{MgO})$. This slag can be characterized as basic slag, because according to the authors Batagin and Esper [15], the mineralogical components of the slag melilitas (akermanita and gehlenita) and marwinita are characteristic of basic slag, as well as wollastonite and anorthite are characteristics of acid slag.

Table 1. Results of the analysis of the chemical composition of CW and LSES.

\begin{tabular}{|c|c|c|}
\hline Elements & Coal Waste $\left(\mu g \cdot g^{-1}\right)$ & $\operatorname{LSES}\left(\mu \mathrm{g} \cdot \mathrm{g}^{-1}\right)$ \\
\hline $\mathrm{Al}$ & 45,013 & 15,558 \\
\hline As & 55.3 & $<90.0$ \\
\hline $\mathrm{Ca}$ & 7110 & 119,228 \\
\hline $\mathrm{Cd}$ & 1.4 & 14.0 \\
\hline Co & 20.8 & $<11.0$ \\
\hline $\mathrm{Cr}$ & 30.4 & 3656 \\
\hline $\mathrm{Cu}$ & 27.8 & 72.5 \\
\hline $\mathrm{Fe}$ & 73,050 & 88,271 \\
\hline $\mathrm{Hg}$ & 0.047 & 0.011 \\
\hline $\mathrm{K}$ & 10,123 & $<650$ \\
\hline $\mathrm{Mg}$ & 224 & 33,434 \\
\hline $\mathrm{Mn}$ & 155 & 11,527 \\
\hline $\mathrm{Na}$ & 1514 & $<200$ \\
\hline $\mathrm{Ni}$ & 28.3 & 87.5 \\
\hline $\mathrm{P}$ & 194 & 653 \\
\hline $\mathrm{Pb}$ & 88.7 & 6.6 \\
\hline $\mathrm{Si}$ & 268,794 & 214,000 \\
\hline $\mathrm{Zn}$ & 94 & 170 \\
\hline $\mathrm{Cl}$ & - & 63.8 \\
\hline $\mathrm{F}$ & - & 5248 \\
\hline
\end{tabular}

Table 2 shows the immediate analysis of CW and LSES in terms of ash, volatile matter, fixed carbon, and total sulfur on a dry basis. It can be observed that the coal waste has $81.3 \%$ of ash, $12.3 \%$ of volatile matter, $5.1 \%$ of fixed carbon, and $10.6 \%$ of total sulfur. The results obtained for the coal waste are consistent with research conducted by Menezes [16], with coal waste from the same coal seam in Santa Catarina, Brazil. The author found $80.4 \%$ of ash, $12.4 \%$ of volatile matter, $7.1 \%$ of fixed carbon, and $9.7 \%$ of total sulfur. The LSES furnace features $100 \%$ of ash, $1.7 \%$ of volatile matter, $0 \%$ of fixed carbon, and $0 \%$ of total sulfur.

The result of the $\mathrm{pH}$ paste for the $\mathrm{CW}$ was 5.3 , showing the tendency of the material to generate acid. LSES depicted the $\mathrm{pH}$ of the slurry as 11.7, indicating high alkalinity. The Fizz Rating, for classifying the fizzy sound produced, showed result "none" for coal waste and "moderate" for the slags. The intensity of the sound is related to the presence of acid consumers' minerals, like calcium and magnesium carbonates or oxides.

The results of acid-generating potential (AP), neutralizing potential (NP), and net neutralization potential (NNP) of the materials are presented in Table 3. The CW had an AP of $331.2 \mathrm{~kg} \cdot \mathrm{CaCO}_{3} \cdot \mathrm{t}^{-1}$ and a NP of 6.8 $\mathrm{kg} \cdot \mathrm{CaCO}_{3} \cdot \mathrm{t}^{-1}$, which resulted in a negative NNP of $324.4 \mathrm{~kg} \cdot \mathrm{CaCO}_{3} \cdot \mathrm{t}^{-1}$, indicating that the material will generate AMD in presence of air and water. This result is in agreement with the results reported in previous works carried out with waste materials from jigging operations in the state of Santa Catarina, where the value of NNP ranged from -300 to $-500 \mathrm{~kg} \cdot \mathrm{CaCO}_{3} \cdot \mathrm{t}^{-1}$ [16-18]. The values of AP and NP of the LSES were 0.9 and 353.1 $\mathrm{kg} \cdot \mathrm{CaCO}_{3} \cdot \mathrm{t}^{-1}$, respectively. The value of the NNP resulted in $352.1 \mathrm{~kg} \cdot \mathrm{CaCO}_{3} \cdot \mathrm{t}^{-1}$. This positive NNP value confirms that the LSES is rich in acid consumer's minerals. Based on the results of NNP, the mixing ratio was settled. The relation obtained was 1 ton of $\mathrm{CW}$ to 1.1 tons of LSES. In practical terms, this value was rounded to a CW:LSES ratio of 1:1. In addition, a CW:LSES ratio of $1: 1.5$ was also used to see whether the addition of

Table 2. Results of the immediate analysis of coal waste and LSES (dry basis).

\begin{tabular}{ccccc}
\hline Parameter & Ash & Volatile Matter & $\mathbf{C}_{\text {Fixed }}$ & $\mathbf{S}_{\text {Total }}$ \\
\hline & $(\%)$ & $(\%)$ & $(\%)$ & $(\%)$ \\
Coal Waste & 82.4 & 12.5 & 5.1 & 10.6 \\
LSES & 100.0 & 0.0 & 0.0 & 0.0 \\
\hline
\end{tabular}

Table 3. Results of static tests for CW and LSES.

\begin{tabular}{ccccccc}
\hline \multirow{2}{*}{ Parameter } & \multirow{2}{*}{$\mathbf{p H}$ Paste } & \multirow{2}{*}{ Fizz Rating } & \multicolumn{2}{l}{$\mathbf{A P}$} & $\mathbf{N P}$ & \multirow{2}{*}{ NNP } \\
\cline { 4 - 5 } & & & \multicolumn{2}{l}{$\mathrm{kg} \cdot \mathrm{CaCO}_{3} \cdot \mathrm{t}^{-1}$} & \\
\hline Coal Waste & 5.3 & none & 331.2 & 6.8 & -324.4 \\
LSES & 11.7 & moderate & 0.9 & 353.1 & 352.1 \\
\hline
\end{tabular}


higher amount of alkaline material, such as $50 \%$ safety factor, would have a superior quality in the leachate. The results of the static tests showed that LSES has promising characteristics that would be used as alkali additives.

Figures 2-3 show the results of the kinetic assay. The test was conducted for 80 weeks to validate the results of the static tests and to determine the quality of water leached in the proposed mixtures of CW and LSES. The behavior of the various parameters analyzed every week was evaluated to observe whether or not the generation of acidity took place.

The results of the leachate $\mathrm{pH}$ of the humid cells along the 80 weeks of testing are shown in Figure 2(a). The $\mathrm{pH}$ values of the leachate from the cell containing only coal waste had a very acid $\mathrm{pH}$ in all analyses, ranging from $\mathrm{pH} 3.1$ to 0.9. Studies by Farfan et al. [19] reported that $\mathrm{pH}$ values below 4.0 and high concentrations of metals are considered the most critical components of the

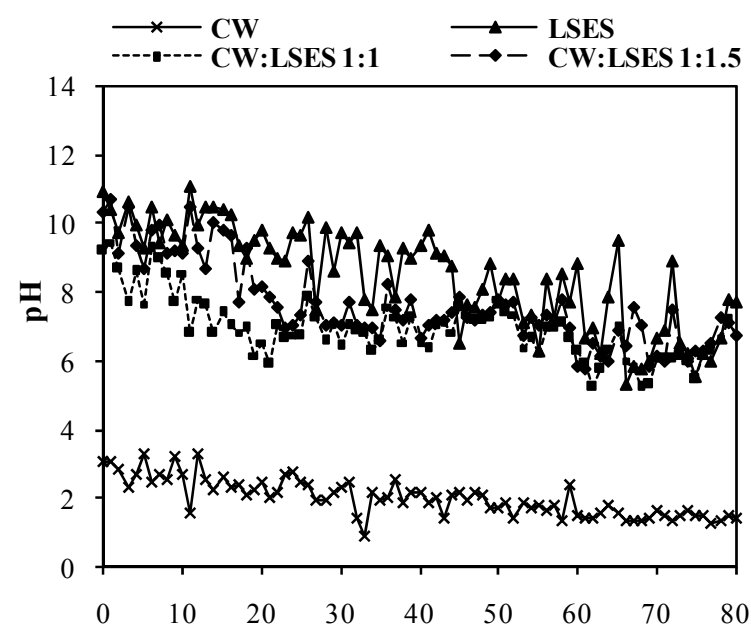

(a) Time (Weeks)

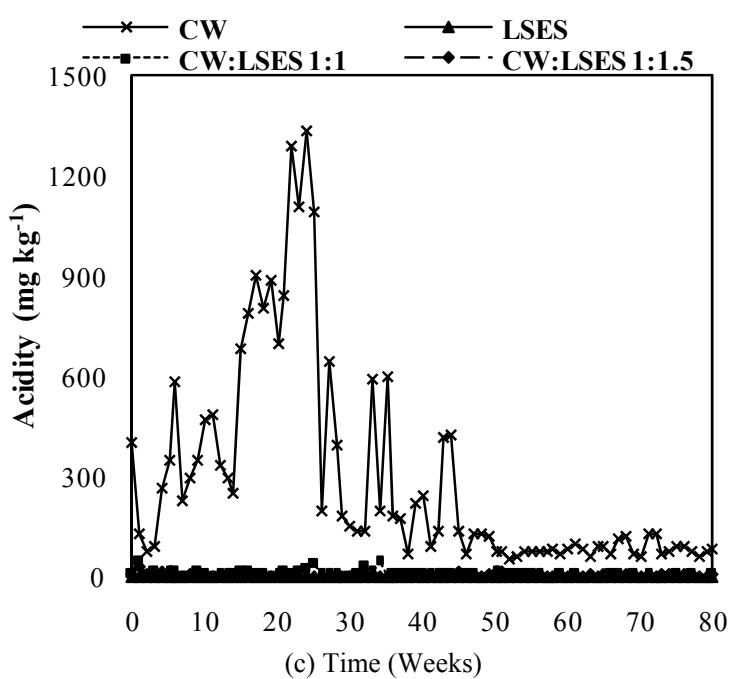

(c) Time (Weeks)
AMD behavior which can also be observed in this experiment. According to the authors, these situations cause oxidation reactions, increasing toxicity in the environment, and acting detrimental to aquatic fauna [19]. With regard to $\mathrm{pH}$, the leachate from the cell containing only LSES was alkaline, getting in the $\mathrm{pH}$ range from 11.0 to 7.7. In the cell containing the mixture of both materials, in a CW-LSES ratio of 1:1, the $\mathrm{pH}$ values were slightly alkaline, starting at 9.2 in the initial weeks and stabilizing at around 6.7 at the end of the trial. The result showed that the proportion of $1: 1$ between the materials avoids acid generation during the 80 week tests. The mixtures of CW and LSES in a ratio of 1:1.5 were also successful, with the $\mathrm{pH}$ varying from 10.7 to 8.1. Both mixtures of $\mathrm{CW}$ with LSES were effective in improving the conditions of $\mathrm{pH}$. The results of leachate $\mathrm{pH}$ for these mixtures were compared with the patterns of release of effluent available at the Brazilian National Council for the Envi-

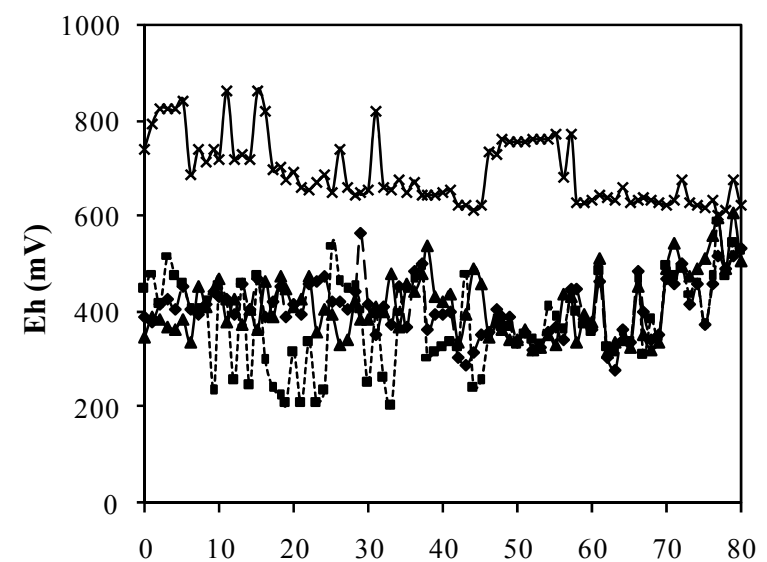

(b) Time (Weeks)

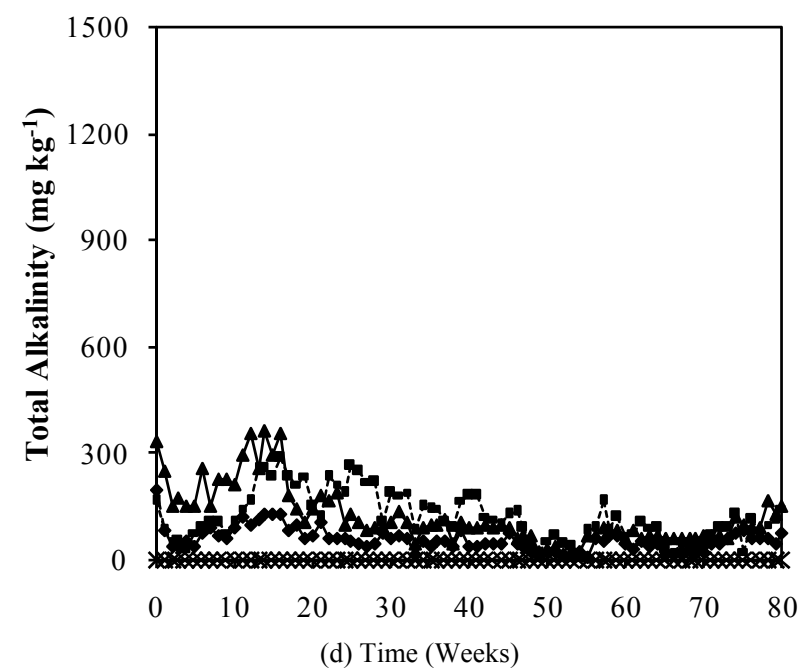

Figure 2. Values of pH (a) and redox potential (b), acidity (c) and total alkalinity (d) of the leachate of the humidity cells with coal waste (CW), ladle slag of electric steelmaking (LSES), coal waste with LSES in the ratio 1:1 (CW:LSES 1:1) and coal waste with LSES in the ratio 1:1.5 (CW:LSES 1:1.5). 


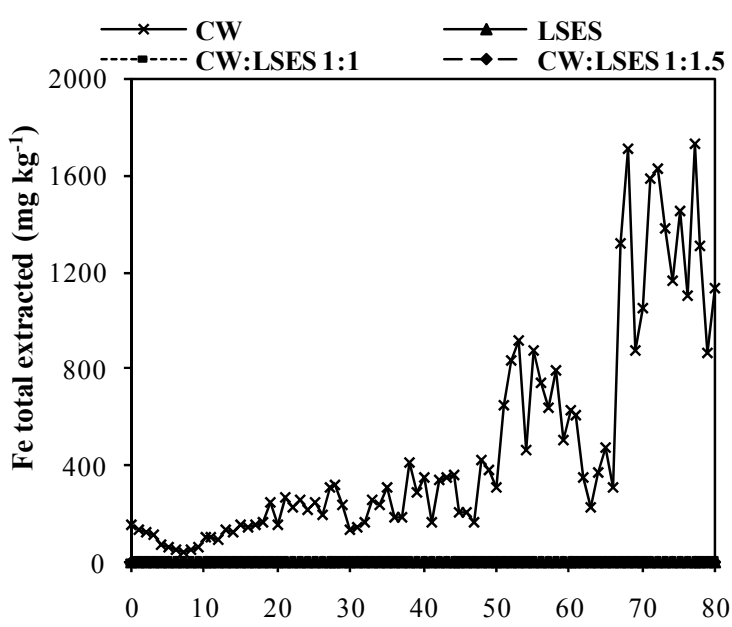

(a) Time (Weeks)
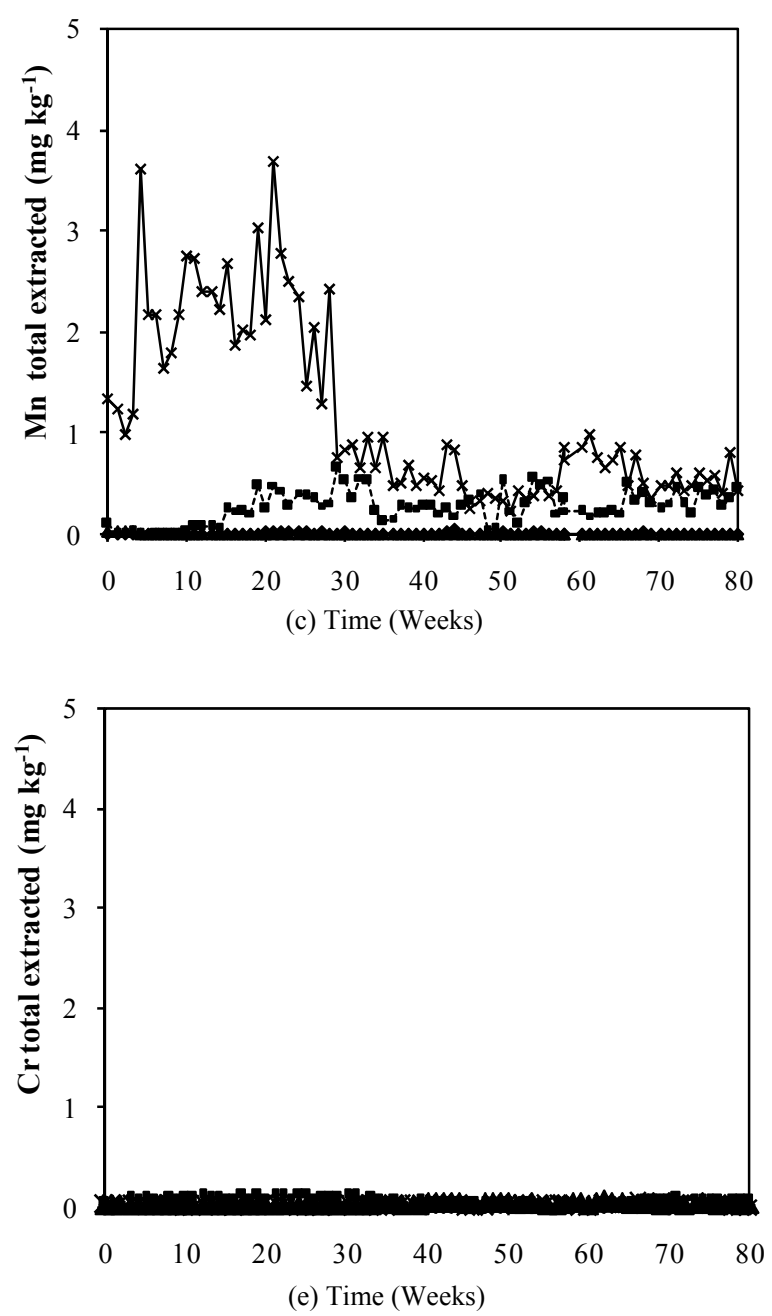

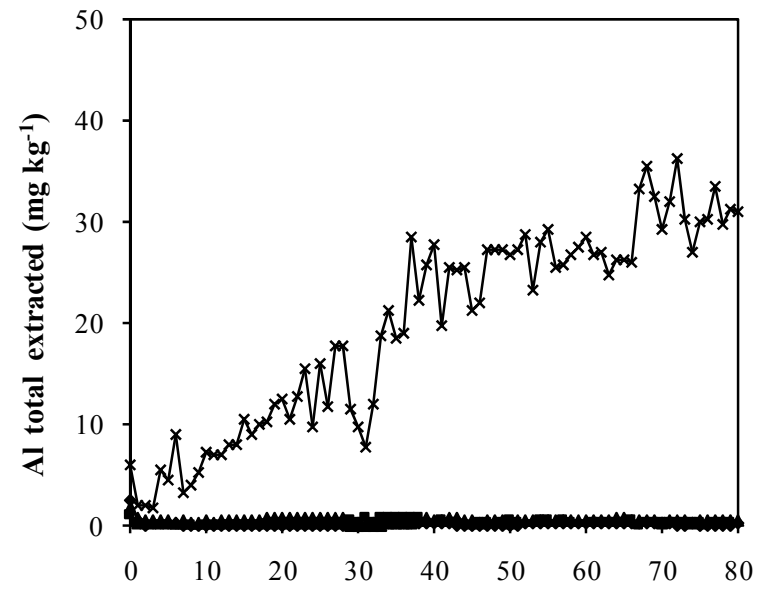

(b) Time (Weeks)

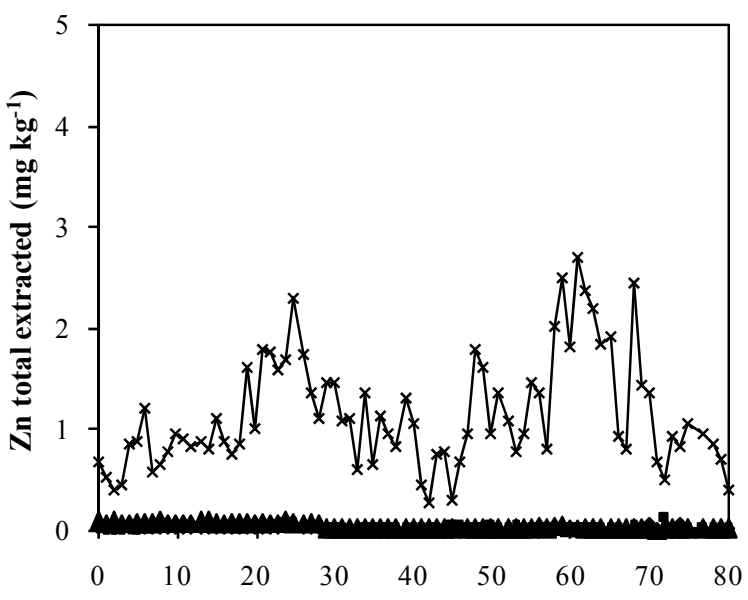

(d) Time (Weeks)

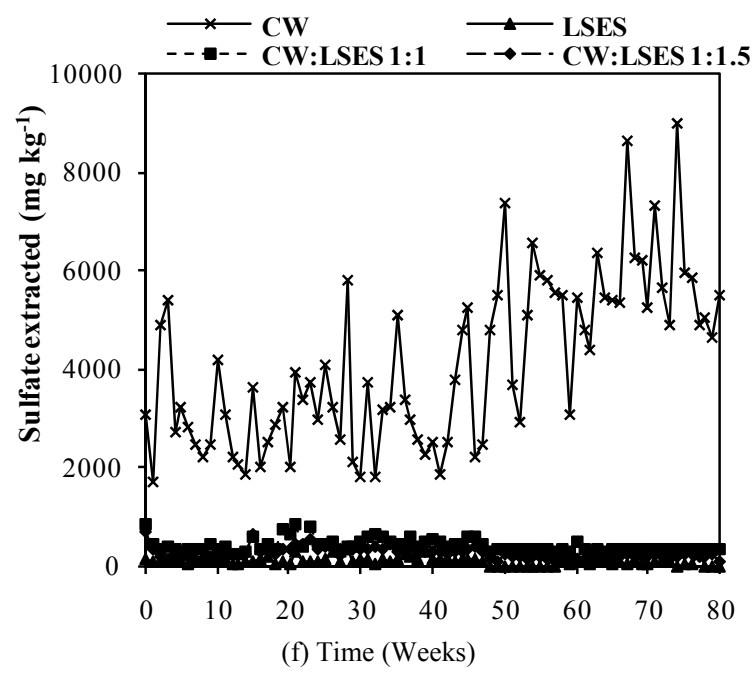

Figure 3. Iron (a), aluminum (b), manganese (c) zinc (d) and chromium (e) and sulfate concentration (f) extracted from humidity cells with coal waste (CW), ladle slag of electric steelmaking (LSES), coal waste with ladle slag of electric steelmaking in the ratio 1:1 (CW:LSES 1:1) and coal waste with ladle slag of electric steelmaking in the ratio 1:1.5 (CW:LSES 1:1.5).

ronment [20]. According to this standard, the effluent may only be released in the receiving water bodies if the $\mathrm{pH}$ is between 5 and 9 . Therefore, the mixture in the ratio of 1:1 attends the emission of the effluent with regard to $\mathrm{pH}$ (with the exception of week 1). So, the amount of alkaline material used was sufficient to avoid pyrite oxidation 
and raise the $\mathrm{pH}$ of the leacheate to the levels established by the Brazilian legislation. Mixing the materials in the proportion of 1:1.5 resulted in $\mathrm{pH}$ values above the emission standards in the firsts 18 weeks of the experiment.

Figure 2(b) shows the results of the potential redox (Eh) for the kinetic test. The analysis of the leachate from the cell containing CW ranged from 862 to $601 \mathrm{mV}$. The values of the redox potential of the leachate from the cell with LSES are smaller than the values of the leachate from the $\mathrm{CW}$, varying in the range $600-320 \mathrm{mV}$. The values of Eh in the leachate from the cell containing CW:LSES 1:1 ranged from 620 to $220 \mathrm{mV}$ and from the cell containing CW:LSES 1:1.5 ranged from 533 to 290 $\mathrm{mV}$. With regard to the leachate Eh of the cell in a 1:1.5 ratio, it can be observed that the values and the variation were smaller than those observed in cell 1:1; so, the oxidation in the cell 1:1.5 was lower than in the cell 1:1. These results are in agreement with Mend Program [21], which says that Eh values larger than $450 \mathrm{mV}$ indicate the oxidation of $\mathrm{Fe}^{3+}$. All cells presented oxidant condition, however the cell containing only $\mathrm{CW}$ is the one with the highest values of redox potential, demonstrating a higher oxidizing condition that favors the oxidation of sulfides.

Figures 2(c) and (d) shows the results of the acidity and alkalinity of the leachate in kinetic experiment. They are important parameter with regard to AMD control by the alkaline additive method [21]. In practice, the materials that compose the mixture could present differences in the kinetics of acid generation and acid consumption. Analyzing the graphs, the cell with CW released high amounts of acidity and no alkalinity during the all assay weeks. Inversely, the leached water of the cell containing LSES showed alkalinity and no acidity. The cells containing mixtures of CW:LSES in the proportion of 1:1 and 1:1.5 presented no acidity and a residual amount of alkalinity. The residual amount of total alkalinity was a little bit higher in the proportion of 1:1.5. Taking into account the acidity and alkalinity of the leachate, it can be concluded that the 1:1 mixture is effective to control the acidity generation of coal waste. These results are consistent with the analysis of the $\mathrm{pH}$ of the leachate showed in Figure 2(a) and the stoichiometric ration established between the materials by the ABA method (Table 3).

Figures 3(a)-(f) show the results of metals extraction $(\mathrm{Fe}, \mathrm{Al}, \mathrm{Mn}$, and $\mathrm{Zn})$ from humidity cells as a function of time. The leachate regarding the cell with $\mathrm{CW}$ showed considerable concentrations of iron, aluminum, manganese, and zinc. Iron is a direct product from pyrite oxidation while aluminum, manganese and zinc were leached from the other minerals that compose the coal waste. The leached water from the cell with only LSES showed very low concentrations of all these metals, close to zero, in- cluding chromium (Figure 3(e)). The cells with the mixtures of CW and LSES, in both proportions of 1:1 and $1: 1.5$, presented very low values of metals extracted, indicating that the presence of LSES inhibited the oxidation of the pyrite, the acidity production and the iron and other metals release.

Figure 3(f) shows the results for the sulfate extraction in the leachate of the humidity cells. In the aliquots obtained from the cell with the $\mathrm{CW}$, sulfate extraction ranged from 1701 to $8639 \mathrm{mg} \cdot \mathrm{kg}^{-1}$ for the 80 week trial. Sulfate production, like iron, is a direct product from pyrite oxidation. The cells containing LSES, CW:LSES 1:1, and CW:LSES 1.15 showed very low concentrations of sulfate in the leached water, showing that the presence of LSES inhibits the pyrite oxidation process.

Through the kinetic assay, it was possible to observe that the leachate from $\mathrm{CW}$ cell presented a lower $\mathrm{pH}$ and a higher concentration of metals and sulfate, demonstrating the pollution potential of the AMD. However, the presence of slag, in both ratio of the 1:1 and 1:1.5, increased the $\mathrm{pH}$, decreased the $\mathrm{Eh}$, and reduced the concentration of metals and sulfate in the leachate. This condition inhibits the oxidation of pyrite, reduces the solubility of the metal and promotes the adsorption of metal compounds on mineral matter [22-24].

\section{Conclusion}

It can be concluded that it is possible to prevent the generation of the AMD by the use of steel slag as an alkaline material. Considering that sample used in this work, it is suggested that a 1:1 mixture of CW and LSES could be used for the prevention of AMD. The neutralization potential is due to the high content of calcium and magnesium oxides present in the slag. This mixture can be used to control AMD in tailing deposits or to return of coal waste into the subsoil (method known as "backfill"). An important aspect to be considered is related to the distribution of materials in the Brazilian market. The steel industry, where these slag samples were collected, has no destination for this slag, discharging them in landfills. Thus, this material presents itself as a potential solution to avoid the AMD.

\section{Acknowledgements}

The authors thank CNPq, CAPES and Network Coal for the financial resources provided for the development of this research.

\section{REFERENCES}

[1] L. P. O. Araújo, "Carvão Mineral," Informativo Mineral 2011. Departamento Nacional de Produção MineralDNPM, Brasília, 2012, pp. 24-25. 
[2] A. Kontopoulos, “Acid Mine Drainage Control,” In: S. H. Castro, F. Vergara and M. A. Sánchez, Eds., Effluent Treatment in the Mining Industry, University of Concepciòn, Edmundo Larenas, 1998, pp. 57-118.

[3] Environmental Protection Agency (EPA), "Acid Mine Drainage Prediction," EPA 530-R-94-036, Technical Document, 1994.

[4] Associação Brasileira De Normas Técnicas (ABNT), "NBR 10007: Amostragem de Resíduos Sólidos," Rio de Janeiro, 2004.

[5] Environmental Protection Agency (EPA), "Method 3052: Microwave Assisted Acid Digestion of Siliceous and Organically Based Matrices," EPA SW-846, Revision 3, Washington DC, 2004.

[6] Associação de Normas Técnicas (ABNT), "NBR 8289: Determinação do Teor de Cinza,” Rio de Janeiro, 1983.

[7] Associação de Normas Técnicas (ABNT), "NBR 8290: Determinação do Teor de Matérias Voláteis," Rio de Janeiro, 1983.

[8] Associação de Normas Técnicas (ABNT), "NBR 8293: Determinação de Umidade," Rio de Janeiro, 1983.

[9] Associação de Normas Técnicas (ABNT), "NBR 8299: Carvão Mineral: Determinação do Carbono Fixo," Rio de Janeiro, 1983.

[10] A. A. Sobek, W. A. Schuller, J. R. Freeman and R. M. Smith, "Field and Laboratory Methods Applicable to Overburden and Minesoils," EPA 600/2-78-054, Environmental Protection Agency, Washington DC, 1978.

[11] American Society for Testing and Material-ASTM, "Test Method for Sulfur in the Analysis Sample of Coal and Coke Using High Temperature Tube Furnace Combustion Methods," ASTM D 4239, 1983.

[12] R. W. Lawerence and Y. Wang, "Determination of Neutralization Potential in the Prediction of Acid Rock Drainage," MEND/NEDEM, Canadian Center for Mineral and Energy Technology, Ottawa, 1997, pp. 449-464.

[13] American Society for Testing and Material-ASTM. "Standard Test Method for Accelerated Weathering of Solid Materials Using a Modified Humidity Cell" ASTM D 5744, 1996.

[14] American Public Health Association (APHA), "Standard Methods for the Examination of Water and Wastewater," 21st Edition, APHA-AWWA-WEF, Washington DC, 2005.

[15] A. F. Batagin and M. W. Esper, "Contribuição ao Conhecimento das Propriedades do Cimento Portland de
Alto-Forno,” ABCP, São Paulo, 1988.

[16] J. C. S. S. Menezes, "Produção de Coagulantes Férricos na Mineração de Carvão," PhD Dissertation, Escola de Engenharia, Programa de Pós-Graduação em Engenharia de Minas, Metalurgia e de Materiais-PPGE3M. Universidade Federal do Rio Grande do Sul-UFRGS, 2009.

[17] Indústria Carbonífera Rio Deserto, “Análise do Potencial de Acidificação e de Neutralização em Rejeitos do Beneficiamento do Carvão Mineral da Região Carbonífera," Technical Report, Rio Desert Company, Santa Catarina, 2004.

[18] D. S. Lilge, M. B. Hahn, I. A. H. Schneider, G. S. R. Silva, K. M. S. Gomes and C. J. B. Gomes, "Ensaios Estáticos e Cinéticos na Previsão da Drenagem Ácida de Minas na mineração de Carvão no sul do Estado de Santa Catarina, RS-Brasil," XXI Encontro Nacional de Tratamento de Minérios e Metalurgia Extrativa, Natal, Universidade Federal do Rio Grande do Norte, CD ROM, 2005.

[19] J. R. J. Z. Farfan, O. F. Barbosa and V. P. Souza, “Avaliação do Potencial de Drenagem Ácida de Rejeitos da Indústria Mineral," CETEM/MCT, Rio de Janeiro, 2004.

[20] Ministério Da Ciência E Tecnologia-Brasil, Conselho Nacional do Meio Ambiente (CONAMA), "Resolução CONAMA n ${ }^{\circ}$ 430," Brasília, 2011.

[21] R. W. Lawrence, G. W. Poling and P. B. Marchant, "Investigations of Predictive Techniques for Acid Mine Drainage," Report 1.16.1a, MEND/NEDEM Canadian Center for Mineral and Energy Technology, Ottawa, 1989.

[22] L. X. L. Capanema and V. S. T. Ciminelli, "An Investigation of Acid Rock Drainage (ARD) Occurrence in a Gold Mine Located in a Southeastern Brazil Region," Revista Escola de Minas. Ouro Preto, Vol. 56. No. 3, 2003, pp. 201-206.

[23] J. Simmons, P. Ziemkiewicz and D. C. Black, "Use of Steel Slag Leach Beds for the Treatment of Acid Mine Drainage," Mine Water and the Environment, Vol. 21, No. 2, 2002, pp. 91-99. http://dx.doi.org/10.1007/s102300200024

[24] D. Feng, J. S. J. Van Deventer and C. Aldrich, "Removal of Pollutants from Acid Mine Wastewater Using Metallurgical By-Products Slags," Separation and Purification Technology, Vol. 40, No. 1, 2004, pp. 61-67. http://dx.doi.org/10.1016/j.seppur.2004.01.003 